\title{
Perancangan Sistem Informasi Persediaan Barang pada Toko Multi Mandiri dengan Metode FIFO (First In First $\mathrm{Out}$ )
}

\author{
Halimah*1 $^{*}$ Amnah ${ }^{2}$ \\ ${ }^{1}$ Jurusan Sistem Informasi, Institut Informatika dan Bisnis Darmajaya; Jalan Zainal Abidin \\ Pagar Alam Bandar Lampung Indonesia 35142, telp/fax 0721-787214/0721-700261 \\ ${ }^{2}$ Jurusan Teknik Informatika, Institut Informatika dan Bisnis Darmajaya, Jalan Zainal Abidin \\ Pagar Alam Bandar Lampung Indonesia 35142, telp/fax 0721-787214/0721-700261 \\ e-mail: *11 halimahyunus@darmajaya.ac.id, ${ }^{2}$ amnah@gmail.com
}

\begin{abstract}
Abstrak
Toko Multi Mandiri adalah Toko yang membuat lemari berbahan dasar almunium di Natar, Lampung Selatan. Kurang mampunya pengendalian persediaan barang secara baik serta tidak lengkapnya pencatatan mengenai informasi persediaan barang, menyebabkan pemilik toko tidak mengetahui dengan jelas kapan harus memesan barang dan akhirnya pemilik toko sering kehabisan persediaan barang dan tidak mampu memenuhi kebutuhan pelangan. Metode dalam alur persediaan barang menggunakan metode FIFO (First In First Out) yaitu persediaan barang dari barang masuk sampai dengan barang keluar, dan untuk metode pengembangan sistemnya menggunakan metode Waterfall. Perangkat lunak pendukung yang digunakan adalah Adobe dreamweaver CS 6, Xampp, Database MySQL, dengan adanya sistem berbasis web, tentunya akan sangat mempermudah pengelolaan data ketersediaan barang serta penjualan, pembelian barang yang dilakukan.
\end{abstract}

Kata kunci-website, persediaan, FIFO

\section{PENDAHULUAN}

Teknologi informasi yang berkembang dapat dimanfaatkan untuk meningkatkan kinerja sebuah perusahaan. Salah satu contohnya yaitu teknologi informasi dimanfaatkan untuk pengolahan data persediaan barang. Penggunaan sistem komputerisasi akan lebih banyak menghemat waktu, tidak menyita banyak tenaga, dan menghasilkan keakuratan penyajian data. Masalah yang berhubungan dengan persediaan barang merupakan masalah umum yang sering dihadapi dalam bidang usaha. Masalah persediaan yang timbul dapat berupa tersedianya barang yang terlalu banyak atau mungkin juga barang yang kurang tersedia atau terlalu sedikit untuk memenuhi permintaan pelanggan.

Toko Multi Mandiri adalah sebuah toko yang membuat lemari berbahan dasar almunium di Natar Lampung Selatan. Toko Multi Mandiri merupakan Toko yang kurang mampu mengendalikan persediaan barang secara baik. Hal ini disebabkan kurang efisiennya sistem yang digunakan seperti, tidak lengkapnya pencatatan mengenai informasi persediaan barang jadi serta toko kesulitan dalam mengetahui penjualan lemari mana yang paling sering dibeli oleh pelanggan. Faktor tersebut menyebabkan toko tidak mengetahui dengan jelas kapan harus memesan bahan baku ke supplier serta pimpinan tidak dapat mengetahui perkembangan penjualan dengan baik.

Sebelumnya terdapat banyak penelitian yang dilakukan mengenai sistem informasi persediaan barang, sehingga dalam upaya pengembangan sistem informasi persediaan barang ini dilakukan kajian pustaka sebagai salah satu alat dari penerapan metode penelitian. Diantaranya adalah menghindari pembuatan ulang (reinventing the wheel), meneruskan penelitian sebelumnya, serta mengetahui area penelitiannya sama dibidang ini. 
Beberapa literature review tersebut adalah sebagai berikut, Penelitian yang dilakukan oleh Sukamdana [1] pada tahun 2016 yang berjudul "Perancangan sistem informasi inventory berbasis web pada PT.Citra gemilang prima". Penelitian menjelaskan tentang pengolahan dan perhitungan data yang terkait dengan persediaan barang, study kasus pada penelitian ini yaitu pada PT. Citra Gemilang (PT.CGP) sebagai perusahaan yang bergerak dibidang penjualan bahan dan makanan olahan seperti sosis, nugget, bakso, dll. Perusahaan ini memiliki masalah proses bisnis yang sangat rentan dengan barang yang akan dijual seperti waktu kadaluarsa barangnya.

Penelitian yang dilakukan oleh Prasetya [2] pada tahun 2011 yang berjudul "pembuatan aplikasi car storage dengan menggunakan metode FIFO (First In First Out) berbasis web". Penelitian ini menjelaskan tentang penyimpanan mobil digudang, study kasus pada penelitian ini yaitu pada PT.Auto 2000 sebagai perusahaan jaringan jasa penjualan, perawatan, perbaikan, dan penyediaan suku cadang TOYOTA. Perusahaan ini memilki masalah dalam penyimpanan mobilnya yaitu belum terdapat sistem yang akurat. Sehingga terkadang unit mobil yang baru masuk kegudang malah dikeluarkan terlebih dahulu padahal terdapat stock yang sudah tersimpan lama jika dihitung dalam masa penyusutan, maka perusahaan akan mengalami kerugian.

Penelitian yang dilakukan oleh Oktapiani [3] tahun 2016 yang berjudul "perancangan sistem persediaan barang menggunakan metode FIFO pada PT.Panjunan sukaraja sukabumi" penelitian ini menjelaskan tentang pengolahan data dan pemesanan barang, study kasus penelitian ini yaitu pada PT.Panjunan Sukaraja Sukabumi adalah perusahaan yang bergerak dibidang distributor makanan ringan. Perusahaan ini memiliki masalah yaitu pada pengolahan data dan pemesanan barang yang pencarian stoknya masih manual dengan cara membandingkan laporan stok barang dan stok fisik barang digudang. Pada tahap implementasi aplikasi persediaan, tidak dapat dilepaskan dengan transaksi pembelian dan penjualan barang. Pada plikasi web dapat menggunakan model keranjang belanja. Aplikasi keranjang belanja lazim ditemui, jika kita sering duduk di depan komputer yang terhubung dengan internet [4]. Aplikasi web dapat digunakan untuk mengembangkan aplikasi keranjang belanja, dengan menggunakan paradigm berorientasi objek untuk meningkatkan produktifitas pemrograman [5]. Pada saat ini aplikasi web telah banyak yang bersifat dinamis, interaktif, dan task oriented untuk digunakan dalam sistem informasi, telekomunikasi, perdagangan, perbankan, dan lain-lain [6].

Argumentasi yang disampaikan oleh Sari [7] menyatakan bahwa perusahaan lebih tepat jika menggunakan metode FIFO dalam menghitung nilai persediaan akhir. Metode FIFO sangat cocok digunakan untuk perusahaan yang menjual barang yang sejenis, cepat kadaluarsa dan model yang cepat berubah. Persediaan merupakan aktiva yang tersedia untuk dijual dalam kegiatan usaha normal dalam proses produksi atau dalam perjalanan berbentuk bahan atau perlengkapan untuk digunakan dalam proses produksi atau pemberian jasa [8]. Metode First In First Out (FIFO) dapat diartikan, bahwa barang yang pertama kali masuk (dibeli) menjadi barang yang pertama kali keluar (dijual).

\section{METODE PENELITIAN}

Metode pengembangan sistem yang digunakan adalah model waterfall yang dapat berisi rancangan/model, pengukuran dan definisi operasional variabel, sampel dan data, tempat dan waktu, teknik pengumpulan data, dan teknik/metode analisis data. Adapun tahapan-tahapan dalam pengembangan sistem dapat dilihat pada Gambar 1 . 


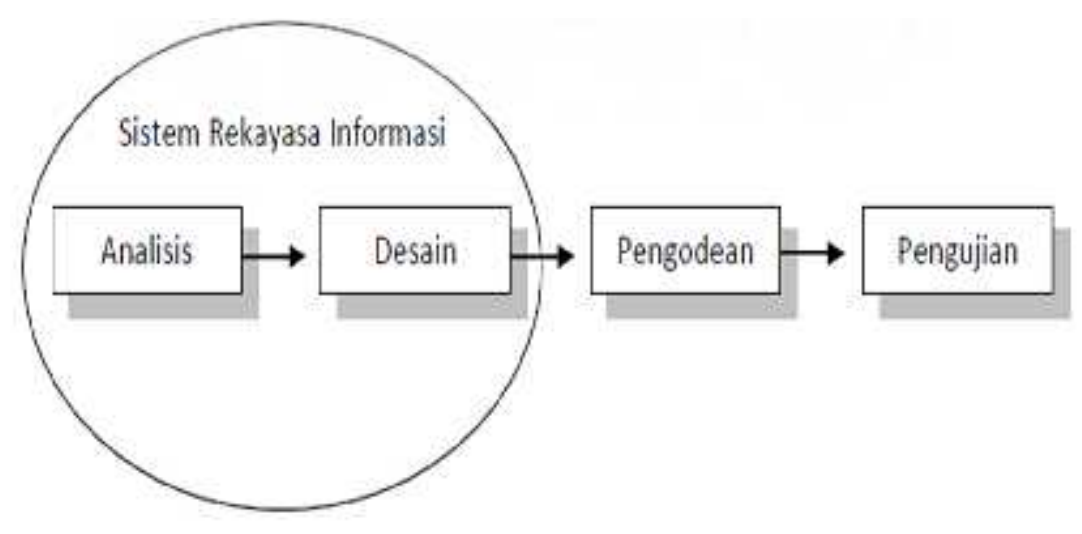

Gambar 1. Metode Waterfall

Gambar 1. Memperlihatkan beberapa tahapan yang dilakukan dalam pengembangan sistem, yang terdiri dari:

1. Analisis

Proses pengumpulan kebutuhan dilakukan secara intensif untuk mespesifikasikan kebutuhan perangkat lunak agar dapat dipahami perangkat lunak seperti apa yang dibutuhkan oleh user. Spesifikasi kebutuhan perangkat lunak pada tahap ini perlu untuk didokumentasikan.

2. Desain

Pada fase ini penulis melakukan perancangan arsitektur menggunakan Document Flowchart, Data Flow Diagram, desain input dan desain output, rancangan database, rancangan kamus data. Pada tahap ini menggunakan alat dan teknik pengembangan sistem serta metode FIFO (First In First Out).

3. Pembuatan Kode program

Desain harus ditranslasikan ke dalam program perangkat lunak. Hasil dari tahap ini adalah program komputer sesuai dengan desain yang telah dibuat pada tahap desain. Pada tahap ini penulis menggunakan bahasa pemrograman PHP dan Database Server MySQL.

4. Pengujian

Pada tahap ini yaitu dilakukan pengujian terhadap sistem yang dibuat dengan menggunakan laptop dan Internet untuk meminimalisir kesalahan pada sistem dan untuk memastikan apakah sistem yang dibuat sesuai denan yang diinginkan.

\section{HASIL DAN PEMBAHASAN}

Hasil implementasi merupakan hasil dari proses-proses yang dilakukan dengan menggunakan metode pengembangan sistem waterfall dimulai dengan tahapan analisis, desain dan pengkodean. Sehingga menghasilkan gambaran dari sistem informasi persediaan barang Toko Multi Mandiri.

\subsection{Halaman Home sebelum Login}

Halaman ini merupakan tampilan paling utama saat custumer membuka website. Berikut Gambar 2 menampilkan tampilan halaman home sebelum login. 


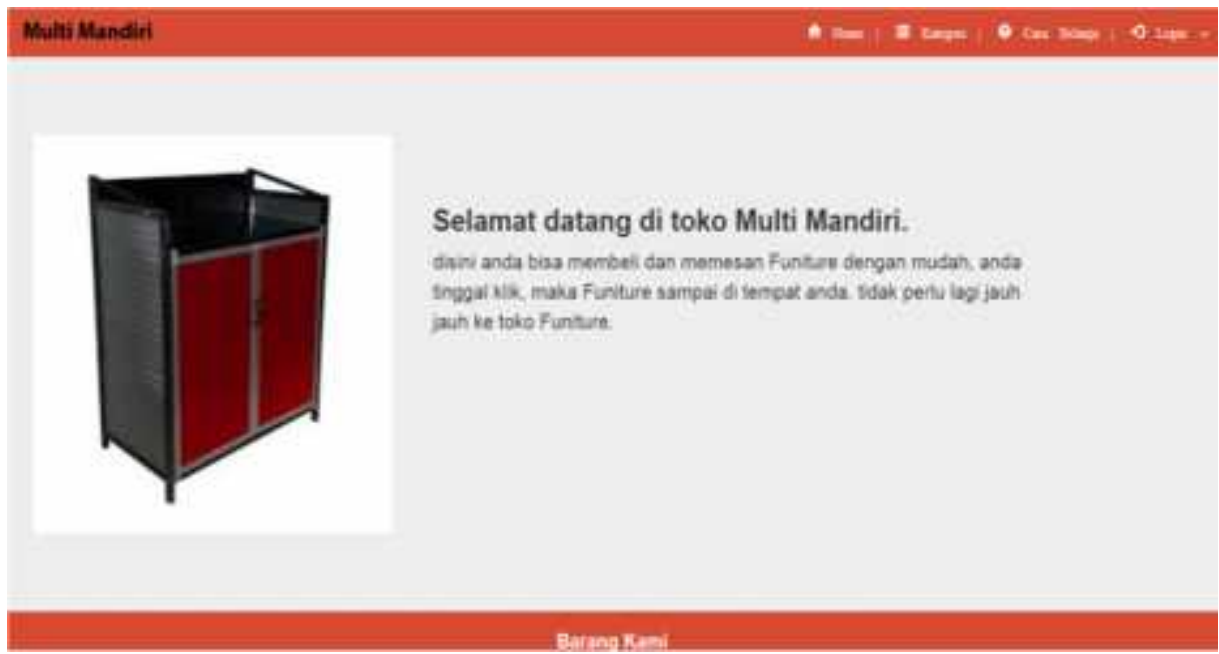

Gambar 2 Hasil Implementasi Halaman Home

\subsection{Halaman Login Customer}

Merupakan halaman akses custumer, yang berisi username dan password. Gambar 3 akan menampilkan implementasi halaman login custumer.

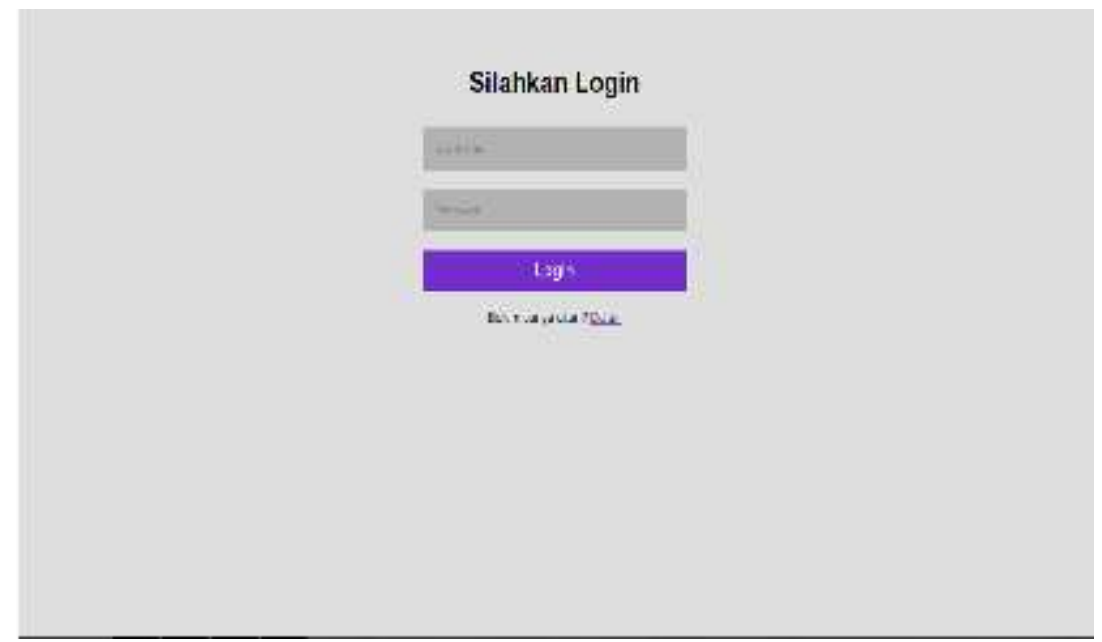

Gambar 3 Hasil Implementasi Halaman Login Custumer

\subsection{Halaman Home Setelah Login}

Halaman ini merupakan tampilan setelah custumer membuka website dan setelah melakukan login. Gambar 4 menampilkan implementasi dari halaman home setelah login. 


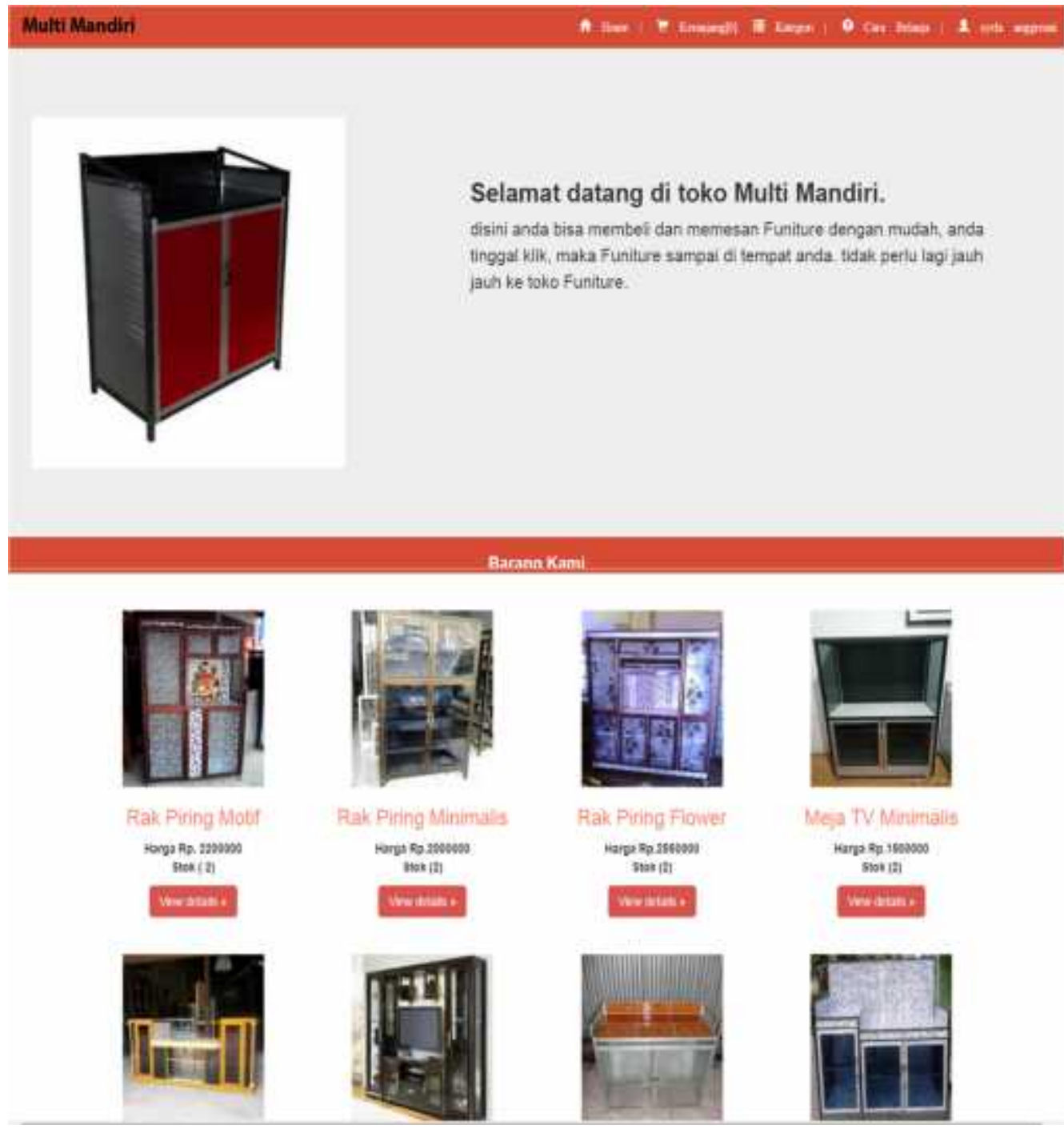

Gambar 4 Hasil Implementasi Halaman Home Setelah Login

\subsection{Halaman Kategori Produk}

Merupakan tampilan setelah custumer login dan memilih menu kategori. Gambar 5 menampilkan implementasi dari halaman kategori produk. 


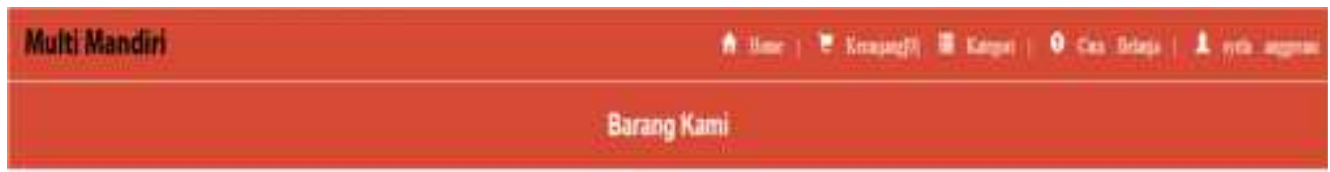

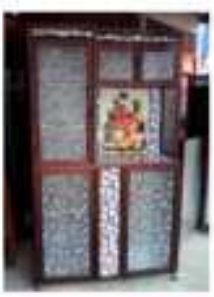

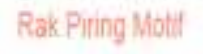

yengs Ap amsso

itat (a)

Watit:

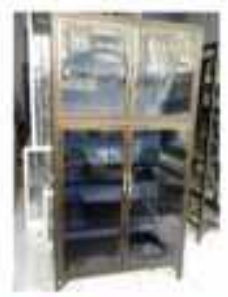

Rạk Pirng Minimalis

Harpiosisoms

Shat $\mid$ t)

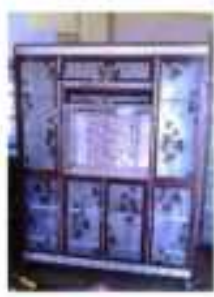

Rak Pling Fidver

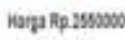

$\max (2)$

Gambar 5 Hasil Implementasi Halaman Kategori Setiap Produk

\subsection{Halaman Keranjang Belanja}

Gambar 6 merupakan tampilan keranjang belanja yang berisi informasi produk yang telah dibeli oleh pelanggan.

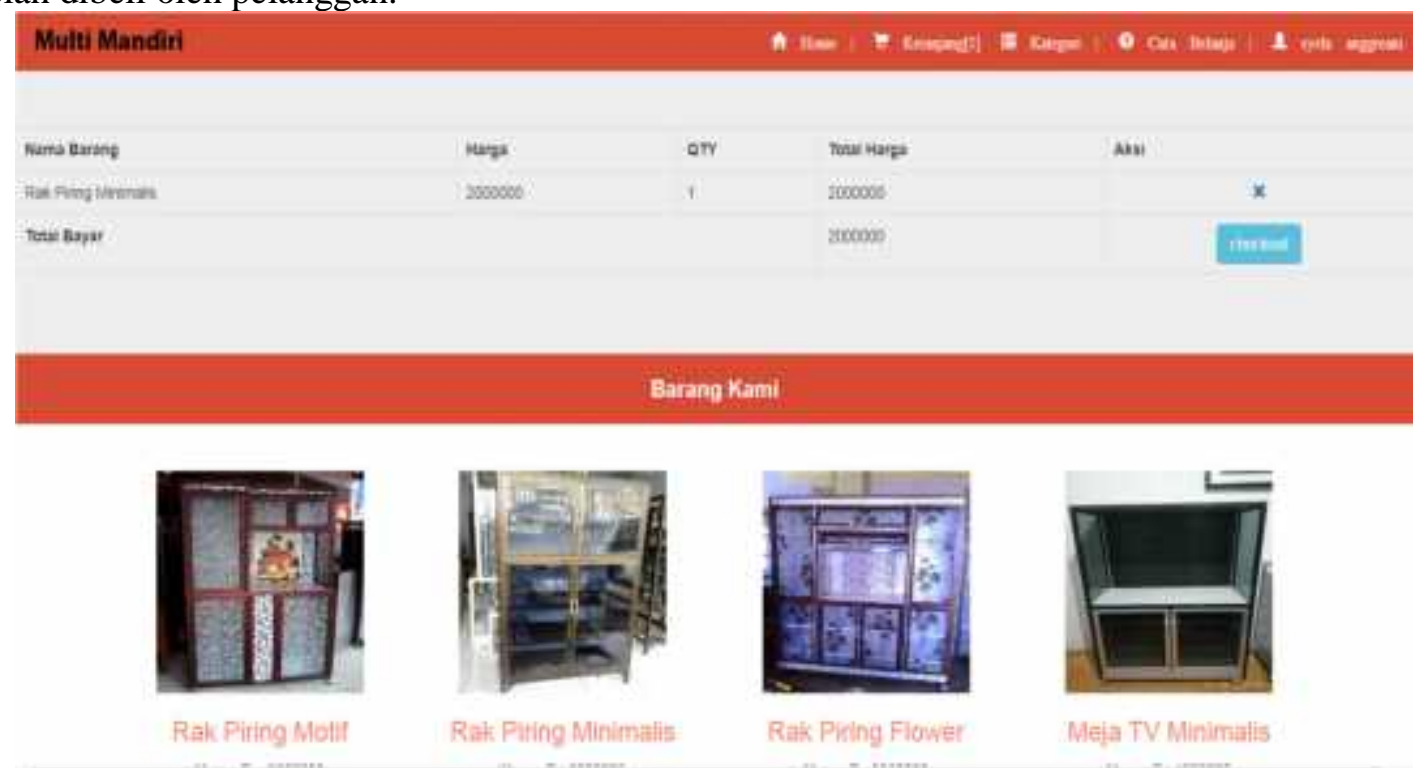

Gambar 6 Hasil Implementasi Halaman Keranjang Belanja

\subsection{Halaman Input Daftar Pemesanan}

Gambar 7 merupakan tampilan halaman pemesanan yang berisi informasi pelanggan yang melakukan transaksi. 


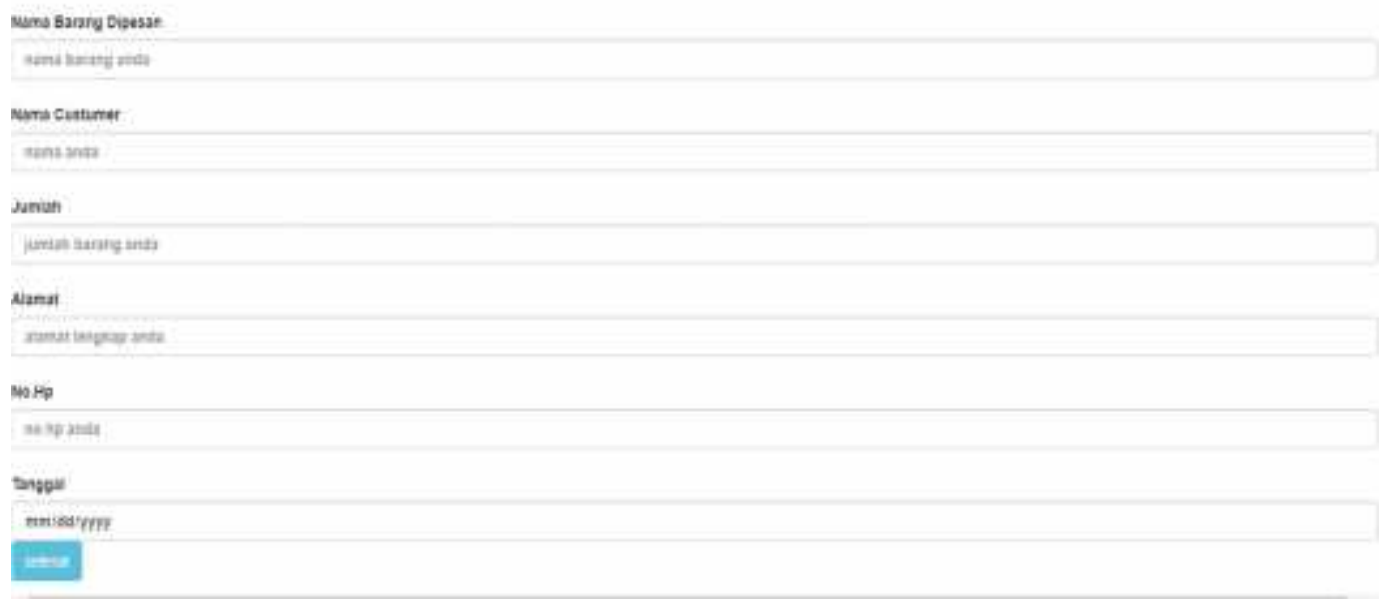

Gambar 7 Hasil Implementasi Halaman Input Daftar Pemesanan

\subsection{Halaman Checkout}

Gambar 8 merupakan halaman checkout untuk mengakhiri proses pembelian barang yang dilakukan oleh customer.

\section{Checkout}

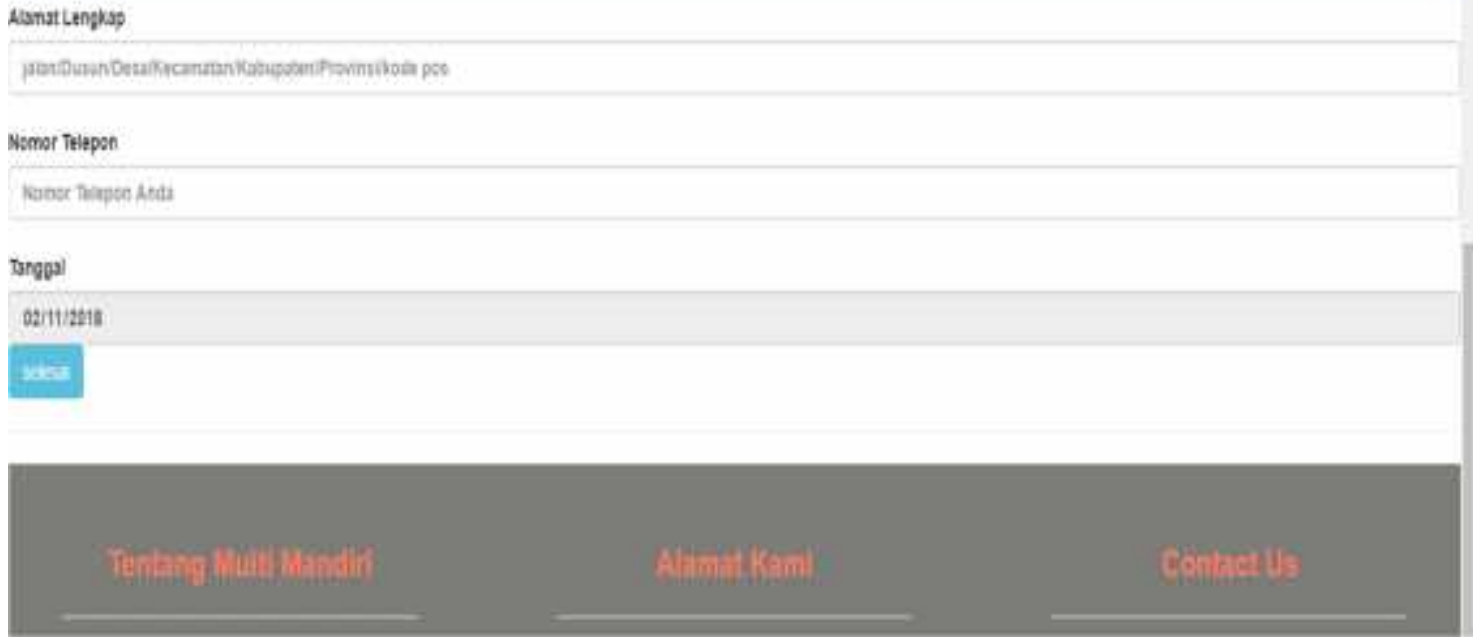

Gambar 8 Hasil Implementasi Halaman Checkout

\subsection{Halaman Cara Belanja}

Merupakan halaman yang memberi informasi kepada custumer bagaimana metode pembayaran yang dilakukan pada website. Gambar 9 akan menampilkan implementasi dari halaman cara belanja. 


\section{Carr Pestan}

1. Pembayaran dilakukan dalam jangka waktu $1 \times 24$ jam setelah melakukan pemesanan.

2. Pembayaran dapat dilakukan melalui transfer ke Rekening kaml. Melalul Konfirmasi Pembayaran.

3. Setelah melakukan pembayaran, konfirmasi pembayaran dikirim ke-

Mega Sari, BANK BRI Daerah Lampung dan sekitarnya, No Rek 0024566737

4. Selanjutnya Funiture yang telah dipesan akan dikirimkan dalam waktu maksimal 7 Hari.

5.Kami mengirimkan barang dengan menggunakan pengiriman via darat

' Harga barang belum termasuk ongkos kirim, dan ongkos kirim akan disesuaikan dengan tujuan pengiriman.

Gambar 9 Hasil Implementasi Halaman Cara Belanja

\subsection{Halaman Konfirmasi}

Halaman konfirmasi berisi informasi konfirmasi barang pembelian yang telah dilakukan. Gambar 10 merupan tampilan halaman konfirmasi.

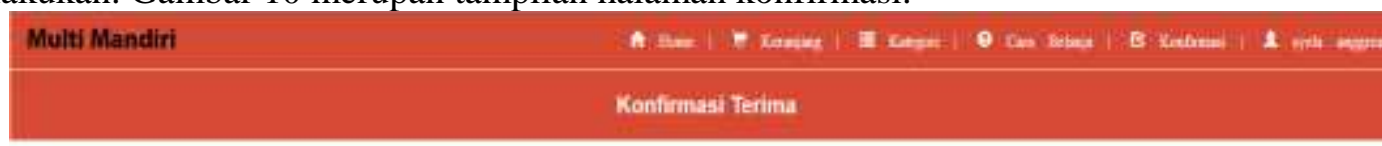

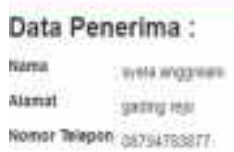

Data Order

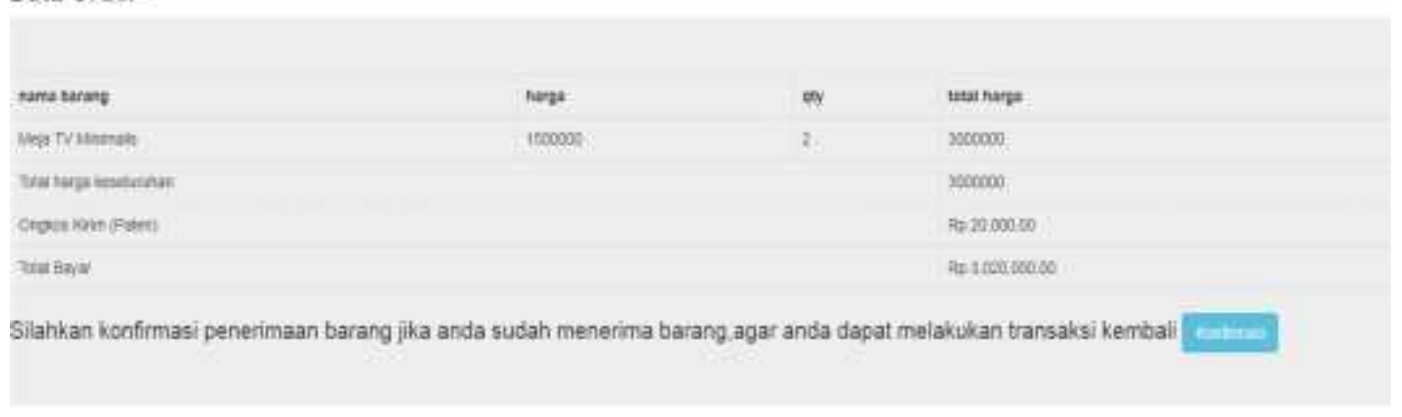

Gambar 10 Hasil Implementasi Halaman Konfirmasi

\subsection{Halaman Pembelian Selesai}

Halaman ini berisi informasi setelah semua proses transaksi selesai dilakukan. Gambar 11 merupakan tampilan pembelian selesai. 

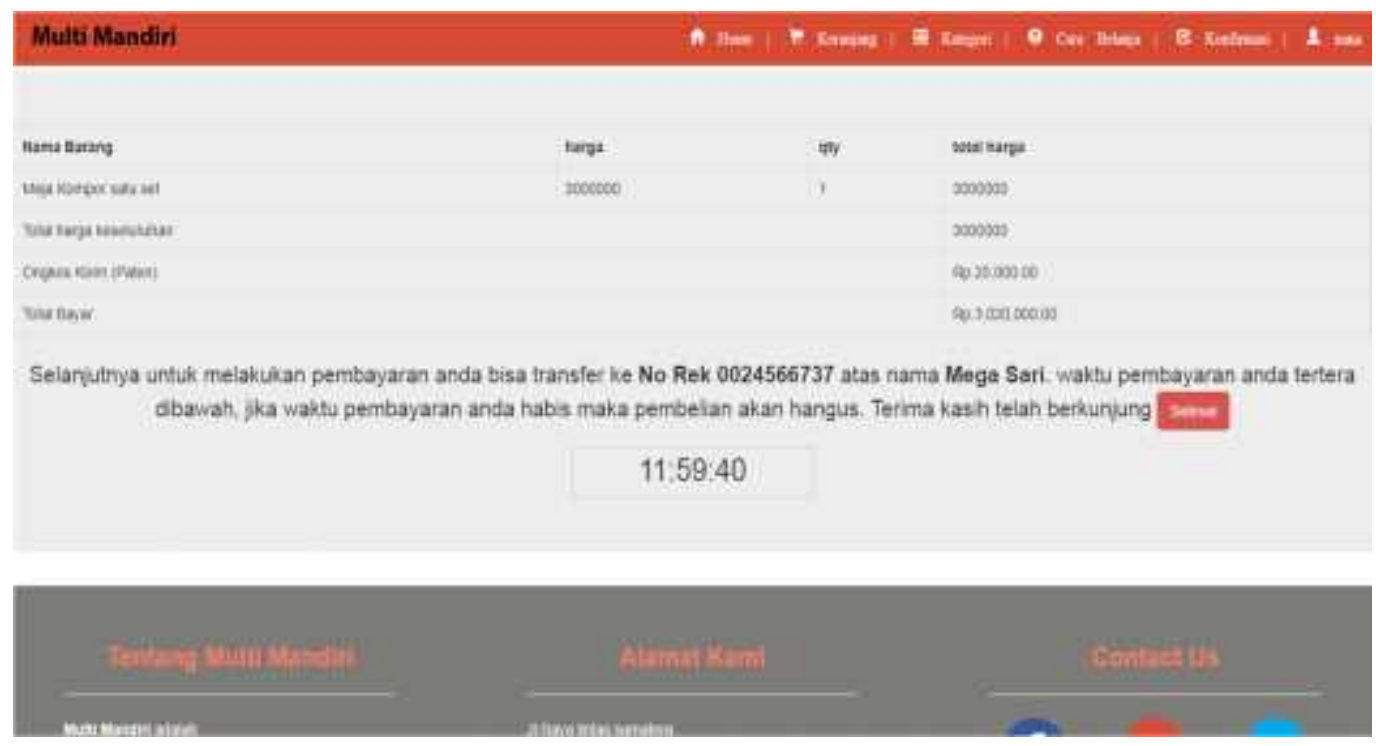

Gambar 11 Hasil Implementasi Pembelian Selesai

Pembahasan ini berisikan proses pembelian barang oleh custumer sampai dengan proses pengelolaan laporan. Dalam sistem yang ditujukan untuk custumer dan pegawai toko ini, akan lebih mudah, menghemat waktu dan tenaga dalam proses pembelian dan penjualan serta mengelola persediaan barang. Aplikasi yang dihasilkan memiliki beberapa kelebihan, diantaranya:

1. Dapat meminimalisir tenaga dalam pembelian barang

2. Mempermudah custumer dalam membeli barang

3. Mempermudah pegawai toko dalam mengelola laporan penjualan dan stok barang

4. Sistem berbasis web sehingga dapat diakses dimanapun dan kapanpun

Disamping itu, aplikasi yang dihasilkan juga memiliki beberapa kekurangan yaitu:

1. Metode pembayaran belum terhubung oleh Indomaret dan Alfamart sehingga harus melakukan pembayaran via transfer bank

2. Sistem ini masih berbasis web bukan mobile

3. Sistem ini belum terhubung pada supplier langsung sehingga harus memesan bahan baku pembuatan lemari secara manual

\section{KESIMPULAN}

Berdasarkan hasil penelitian dan pembahasan dari bab sebelumnya maka dapat diambil beberapa kesimpulan sebagai berikut :

1. Sistem ini dapat dijadikan sebagai media baru bagi Toko Multi Mandiri untuk mengelola persediaan, penjualan, dan laporan

2. Mempermudah proses penjualan dan pembelian karena dapat diakses diinternet tanpa harus datang ke toko.

3. Mempermudah proses perhitungan stok barang karena secara otomatis dihitung oleh sistem

4. Mempermudah dan mempercepat proses pembuatan laporan penjualan dan stok barang.

\section{SARAN}

Saran yang dapat penulis sampaikan kepada pengguna untuk lebih meningkatkan manfaat sistem yang telah dibuat yaitu : 
1. Sistem selanjutnya diharapkan dapat dikembangkan lagi sesuai kebutuhan dan dapat terhubung ke bank-bank lain

2. Diharapkan sistem dapat terhubung langsung dengan supplier-supplier yang bekerja sama dengan toko, agar proses pemesanan bahan baku pembuatan lemari dapat dilakukan dengan system

3. Desain program dan laporan yang masih sederhana agar terus dikembangkan sehingga mempunyai banyak pilihan model atau desain laporan

4. Diharapkan sistem dapat dikembangkan lagi menjadi lebih canggih yaitu berbasis mobile atau android

\section{UCAPAN TERIMA KASIH}

Penulis mengucapkan terima kasih kepada jurnal redaksi Jupiter yang telah memberikan kesempatan kepada penulis, sehingga artikel ilmiah ini dapat dipublikasikan.

\section{DAFTAR PUSTAKA}

[1] Sukamdana, B., 2016, Perancangan Sistem Informasi Inventory Berbasis Web pada PT Citra Gemilang Prima, Jurnal Sistem Informasi, http://digilib.esaunggul.ac.id/public/UEUUndergraduate-8429-jurnal.pdf, diakses November 2017.

[2] Prasetya, E.B., 2017, Pembuatan Aplikasi Car Storage Dengan Menggunakan Metode FIFO Berbasis Web, Jurnal Elektrum, Volume 14, Nomor 1, 45 - 51, https://jurnal.umj.ac.id/index.php/elektum/article/download/1339/1281.

[3] Oktapiani, R., Prianto, D., Riniawati, R., Suherman, A., 2016, Perancangan Sistem Persediaan Barang Menggunakan Metode FIFO pada PT. Panjunan Sukaraja Sukabumi, http://seminar.bsi.ac.id/knist/index.php/knist-2017/article/view/20, diakses 2 November 2017.

[4] Amin, M.M., 2009, Shortcourse Membuat Aplikasi Keranjang Belanja, http://ilmukomputer.org/wp-content/uploads/2016/08/amin-keranjang-belanja.pdf, diakses tanggal 25 Desember 2017

[5] Amin, M.M., 2010, Pengembangan Aplikasi Web Menggunakan PHP Data Object (PDO), Penerbit Graha Ilmu, Yogyakarta.

[6] Bakhtiar, K. Sistem Informasi Pemesanan Tiket Berbasis Web pada Perum Damri Palembang Menggunakan Metode Waterfall, JUPUTER (Jurnal Penelitian Ilmu dan Teknologi Komputer), Vol. 10, No. 1, April 2018, 9 - 18

[7] Sari, D.I. 2018. Analisis Perhitungan Persediaan dengan Metode FIFO dan Average pada TT. Harapan. Jurnal Persepksif, Vol. XVI, No. 1, Maret 2018, 31 - 38

[8] Hermawan, S., 2008, Akuntansi Perusahaan Manufaktur, Penerbit Graha Ilmu, Yogyakarta

[9] Agus, I., \& Indera, I. (2017). Perencanaan Strategis Sistem Informasi Administrasi yang Terintegrasi Pada Lembaga Pendidikan Tinggi. JUPITER (Jurnal Penelitian Ilmu dan Teknik Komputer), 9(2). 